\title{
SUBLINGUAL MISOPROSTOL VS SUBLINGUAL MISOPROSTOL WITH VAGINAL ESTRADIOL FOR LABOR INDUCTION
}

\author{
By
Eslam N. A. A. Abd El-Razek, Abdullah K. Ahmed and Al-Refaai A. Marai \\ Department of Obstetrics and Gynecology, Faculty of Medicine, Al-Azhar University \\ (Cairo) Egypt \\ E-mail: $\underline{\text { es.nabl01@gmail.com }}$
}

\begin{abstract}
Background: Induction of labor is usually performed when the risks of continuing pregnancy are higher than the benefits of delivery. Uterine cervical tissue ripening or its softening has a close relationship with success rate of delivery.

Objective: To compare the safety and effectiveness of sublingual misoprostol with combined sublingual misoprostol and vaginal estradiol for induction of labor in unfavorable cervix.

Subjects and methods: This was a prospective single blinded study conducted in Obstetrics and Gynecology Departments, El-Hussein University Hospital ELAlamin Standard Hospital, Matrouh including 160 women with unfavorable cervix and gestation $\geq 40$ till 42 weeks with clinical indication for induction of labor. They would be randomly assigned to either the misoprostol+ placebo or misoprostol+ estradiol. The duration of the study was 12 months from 01 May 2019 till 01 may 2020.

Results: Women's Time to active labor in women with misoprostol+ placebo ranged between 5-9 hours with mean \pm S.D. $6.99 \pm 1.419$ hours while in women with misoprostol+ estradiol was ranged between 5-9 hours with mean \pm S.D. $6.96 \pm 1.400$ hours. There were no statistically significant differences between groups.

Conclusion: Sublingual misoprostol alone was as effective as sublingual misoprostol and vaginal Estradiol for induction of labor at term.

Keywords: Induction, unfavorable, sublingual, misoprostol, Estradiol.

\section{INTRODUCTION}

The success of induction of labor is influenced by a combination of events existing prior to initiation of labor, such as Braxton Hicks contractions, ratio of estrogen to progesterone, prostaglandin synthesis, and the state of cervical collagen matrix. Labor induction in presence of unfavorable cervix is often prolonged, tedious, and may lead to induction failure. The failure rate with an

unfavorable cervix range from 25 to $50 \%$. Hence cervical ripening is required before induction of labor to achieve more successful outcome (Iliodromiti et al., 2012).

Prostaglandins play a critical role in cervical ripening by increasing inflammatory mediators in the cervix and inducing cervical remodeling. Prostaglandin E1 (PGE1) and prostaglandin E2 (PGE2) exert different
\end{abstract}


effects on these processes and on myometrial contractility. These mechanistic differences may affect outcomes in women treated with dinoprostone, a formulation identical to endogenous PGE2, compared with misoprostol, a PGE1 analog. The objective of this review is to evaluate existing evidence regarding mechanistic differences between PGE1 and PGE2, and considers the clinical implications of these differences in patients requiring cervical ripening for labor induction (Bakker et al., 2017).

The present study aimed to compare between using misoprostol alone sublingually VS misoprostol sublingually and estradiol vaginally as regard to safety and efficacy in induction of labor.

\section{PATIENTS AND METHODS}

A prospective single blinded study was conducted at the Obstetrics and Gynecology Departments at El-Hussin University and Hospitals and EL- Alamin Standard Hospital, Matrouh from 2019 to 2020.

The study had been carried out on total of 160 women with unfavorable cervix and gestation $\geq 40$ till 42 weeks with clinical indication for induction of labor. They had been randomly assigned to either the misoprostol placebo or misoprostol estradiol.

All patients had been subjected to complete history taking personal history, obstetric history, present history, past history and surgical history of operation, laparoscopic interference.

\section{Examination:}

A. General examination.
B. Abdominal and local clinical examination.
C. Bimanual pelvic examination.
D. Investigations: Complete blood count a coagulation profile.
E. Ultrasound Estimated fetal weight, gestational age, AFI and umbilical Doppler.

\section{Outcome measures of the study as following:}

Primary Outcome: Measure the time to cervical ripening.

Secondary Outcome: Measure the time to active labor, Number of misoprostol doses, Induction delivery time and fetal outcome (APGAR score).

Ethical Consideration: This Study had been submitted for approval by Institution Research Board (IRB) of Faculty of Medicine Al-Azhar University. An Informed verbal consent had been obtained from each participant sharing in the study. Confidentiality and personal privacy had been respected in all levels of the study.

\section{Data management and Statistical Analysis:}

Data collected throughout history, basic clinical examination, laboratory investigations and outcome measures coded, entered and analyzed using Microsoft Excel software. Data were then imported into Statistical Package for the Social Sciences (SPSS version 20.0).

Tests used were Fisher's exact test and Mann-Whitney test, and $\mathrm{P}$ value $<0.05$ was considered significant. 


\section{RESULTS}

Women's Gestational age in women with misoprostol + placebo was ranged between 40-42 weeks with mean \pm S.D. $40.94 \pm 0.852$ weeks while in women with misoprostol estradiol was ranged between
40-42 weeks with mean \pm S.D. $40.88 \pm 0.857$ weeks. There were no statistically significant differences between groups where $\mathrm{P}=0.658$ (Table 1).

Table (1): Comparison between two groups as regard to patient's Gestational age

\begin{tabular}{|c|c|c|c|}
\cline { 1 - 3 } $\begin{array}{l}\text { Gestational Groups } \\
\text { age }\end{array}$ & $\begin{array}{c}\text { Misoprostol + } \\
\text { placebo } \\
(\mathbf{n = 7 9 )}\end{array}$ & $\begin{array}{c}\text { Misoprostol } \\
+ \text { estradiol } \\
(\mathbf{n = 8 1})\end{array}$ & \multirow{2}{*}{ MwP Value } \\
\cline { 1 - 3 } Min.-Max. & $40-42$ & $40-42$ & \multirow{2}{*}{0.658} \\
\hline Mean \pm S.D & $40.94 \pm 0.852$ & $40.88 \pm 0.857$ & \\
\hline
\end{tabular}

MW: Mann-Whitney test of significance

Women's mode of delivery in women with misoprostol + placebo show that $41(51.9 \%)$ mode of delivery were NVD and $38(48.1 \%)$ had Caesarean delivered while in women with misoprostol estradiol 40(49.4\%) mode of delivery were NVD and 41(50.6\%) had Caesarean. There were no statistically significant differences between groups where $\mathrm{P}=0.750$ (Table 2).

Table (2): Comparison between two groups as regard to patient's mode of delivery

\begin{tabular}{|c|c|c|c|c|c|}
\hline \multirow{2}{*}{ Mode of delivery } & \multicolumn{2}{|c|}{$\begin{array}{c}\text { Misoprostol + } \\
\text { placebo } \\
(\mathbf{n = 7 9 )}\end{array}$} & \multicolumn{2}{|c|}{$\begin{array}{c}\text { Misoprostol + } \\
\text { estradiol } \\
(\mathbf{n = 8 1})\end{array}$} & \multirow{2}{*}{$\begin{array}{c}\text { FEP } \\
\text { Value }\end{array}$} \\
\cline { 2 - 5 } & $\mathbf{N o .}$ & $\mathbf{\%}$ & No. & \% & \\
\hline NVD & 41 & 51.9 & 40 & 49.4 & \multirow{2}{*}{0.750} \\
\hline Caesarean & 38 & 48.1 & 41 & 50.6 & \\
\hline
\end{tabular}

FE: Fisher's Exact test of significance

Women's Time to active labor in women with misoprostol + placebo was ranged between 6-9 hours with mean \pm S.D. $7.53 \pm 1.107$ hours while in women with misoprostol estradiol was ranged between 5-12 hours with mean \pm S.D. 7.90 \pm 2.221 hours. There were no statistically significant differences between groups where $\mathrm{P}=0.920$ (Table 3).

Table (3): Comparison between two groups as regard to patient's Time to active labor

\begin{tabular}{|c|c|c|c|}
\hline $\begin{array}{c}\text { Time to } \\
\text { active labor }\end{array}$ & $\begin{array}{c}\text { Misoprostol + } \\
\text { placebo } \\
(\mathbf{n = 7 9 )}\end{array}$ & $\begin{array}{c}\text { Misoprostol + } \\
\text { estradiol } \\
(\mathbf{n = 8 1})\end{array}$ & \multirow{2}{*}{ Mw P Value } \\
\cline { 1 - 2 } Min.-Max. & $6-9$ & $5-12$ & \multirow{2}{*}{0.188} \\
\hline Mean \pm S.D & $7.53 \pm 1.107$ & $7.90 \pm 2.221$ & \\
\hline
\end{tabular}

MW: Mann-Whitney test of significance 
Women's Number of misoprostol doses in women with misoprostol + placebo was ranged between 1-3 with mean \pm S.D. $1.96 \pm 0.629$ while in women with misoprostol estradiol was ranged between 1-3 with mean \pm S.D. 2.02 \pm 0.612 . There were no statistically significant differences between groups where $\mathrm{P}=0.522$ (Table 4).

Table (4): Comparison between two groups as regard to patient's Number of misoprostol doses

\begin{tabular}{|c|c|c|c|}
\hline $\begin{array}{c}\text { Number of } \\
\text { misoprostol } \\
\text { doses }\end{array}$ & $\begin{array}{c}\text { Misoprostol + } \\
\text { placebo } \\
(\mathbf{n = 7 9 )}\end{array}$ & $\begin{array}{c}\text { Misoprostol + } \\
\text { estradiol } \\
(\mathbf{n = 8 1})\end{array}$ & \multirow{2}{*}{${ }^{\text {MwP Value }}$} \\
\cline { 1 - 3 } Min.-Max. & $1-3$ & $1-3$ & \multirow{2}{*}{0.522} \\
\hline Mean \pm S.D & $1.96 \pm 0.617$ & $2.02 \pm 0.618$ & \\
\hline
\end{tabular}

MW: Mann-Whitney test of significance

Women's Gestational age in women with misoprostol + placebo was ranged between 5-10 with mean \pm S.D. 7.56 \pm 1.542 while in women with misoprostol estradiol was ranged between 5-10 with mean \pm S.D. $7.69 \pm 1.729$. There were no statistically significant differences between groups where $\mathrm{P}=0.593$. Relation between APGAR score and each of mode of delivery and cause of CS show no statistically significant differences between groups (Table 5).

Table (5): Comparison between two groups as regard to patient's Fetal Outcome (APGAR score)

\begin{tabular}{|c|c|c|c|}
\hline $\begin{array}{c}\text { Fetal Outcome (APGAR } \\
\text { score) }\end{array}$ & $\begin{array}{c}\text { Misoprostol + } \\
\text { placebo } \\
(\mathbf{n}=79)\end{array}$ & $\begin{array}{c}\text { Misoprostol + } \\
\text { estradiol } \\
(n=81)\end{array}$ & $\begin{array}{l}{ }^{M W} \mathbf{P} \\
\text { Value }\end{array}$ \\
\hline Min.-Max. & $5-10$ & $5-10$ & \multirow{2}{*}{0.593} \\
\hline Mean \pm S.D & $7.56 \pm 1.542$ & $7.69 \pm 1.729$ & \\
\hline NVD & $7.39 \pm 1.547$ & $7.90 \pm 1.676$ & \multirow{2}{*}{0.684} \\
\hline CS & $7.74 \pm 1.537$ & $7.49 \pm 1.777$ & \\
\hline
\end{tabular}

MW: Mann-Whitney test of significance

\section{DISCUSSION}

Several methods have been used for the induction of labor and termination of pregnancy with different degrees of safety and success, and many investigations have been performed on this topic. Nonetheless, a consensus has yet to emerge about the most appropriate method for all women (Jahromi et al., 2016).

Vaginal and sublingual misoprostol have a rapid onset action, due to their prolonged activity and bioavailability. A sublingual dose of $50 \mathrm{mg}$ every $4 \mathrm{~h}$ in most of cases, induce vaginal delivery within 24 hours and compared to an equivalent oral dose, less oxytocin augmentation is required. However, the previous studies found few significant differences among the effectiveness of different doses of the Misoprostol, oral, vaginal or sublingual (Fakoor et al., 2013). 
The main objective of our study was to compare the safety and effectiveness of sublingual misoprostol with combined sublingual misoprostol and vaginal estradiol for induction of labor in unfavorable cervix.

Women's gravity in women with misoprostol + placebo was ranged between $1-3$, while in women with misoprostol estradiol was ranged between $1-3$. There were no statistically significant differences between groups. There were no statistically significant differences between groups regarding women's parity.

Our results supported by study of Dasgupta and Singh. (2012), as they conducted study to assess the effect of Vaginal Misoprostol vs Vaginal Misoprostol with Estradiol for Labor Induction and they found that there were no statistically significant differences between groups regarding the age and parity.

Furthermore, Tanha et al. (2013), reported that there was no statistically significant difference in women's age, gestational age, number of previous pregnancies, miscarriages and termination of pregnancies between the two groups. $40.2 \%$ patients were primiparous and 59.2 $\%$ were multiparous. In the vaginal group, $38.8 \%$ patients were nulliparous and 61.1 $\%$ were multiparous. In sublingual group, $41.7 \%$ were nulliparous and $58.2 \%$ were multiparous.

According to Ayati et al. (2014), there was no significant difference in the demographic characteristics between two studied groups of women.
Regarding Dickinson et al. (2014) there were no significant differences between the groups regarding maternal age or gestational age.

Induction of labor is usually performed when the risks of continuing pregnancy are higher than the benefits of delivery. Undoubtedly, uterine cervical tissue ripening or its softening has a close relationship with success rate of delivery (Mirteimouri et al., 2012).

Around $20 \%$ of all deliveries were preceded by labor induction. Prolonged pregnancy and maternal hypertensive disorders being the major indications for the last 50-60 years. The 'other' indications are ante partum hemorrhage, diabetes mellitus, red-cell alloimmunization, demonstrable placental failure and previous unexplained still birth at term (Hofmeyr et al., 2010).

In the present study, women's indications for inductions in women with misoprostol + placebo showed $51.9 \%$ with postdatism, $48.1 \%$ with PROM, $44.3 \%$ with PIH and $53.2 \%$ with IUGR, while in women with misoprostol estradiol $50.6 \%$ with postdatism, $49.4 \%$ with PROM, $48.1 \%$ with PIH and $58 \%$ with IUGR. There were no statistically significant differences between groups.

Women's time to active labor in women with misoprostol + placebo ranged between 5-9 hours while in women with misoprostol estradiol was ranged between 5-9 hours. There were no statistically significant differences between groups.

Our results were in line with study of MacIntyre et al. (2012) as they reported that there were no differences among the 
three groups as to the distribution of these medical obstetric complications.

According to Tanha et al. (2013) induction to termination period does not differ significantly between the two groups.

Dodd and Crowther (2010) evaluated sublingual versus vaginal misoprostol for induction of labor at term, found that there was no difference between groups in case of induction to delivery interval and duration of labor.

In contrary with our results, study of Dasgupta and Singh (2012) as they found that time required for cervical ripening, time required for starting of active and time required for delivery in vaginal delivery cases were found significantly less in combined estradiol and misoprostol group. In misoprostol group, induction initiation to cervical ripening interval, induction initiation to active labor initiation and induction initiation to delivery. Other studies have also shown intervals of similar duration (Khadem and Khadivzadeh., 2015).

The current study shows that women's Number of misoprostol doses in women with misoprostol + placebo ranged between 1-3 with while in women with misoprostol estradiol ranged between 133. There were no statistically significant differences between groups.

Our results are supported by study of Ayati et al. (2014) as they found that findings showed that there weren't any statistically significant differences between the numbers of administered doses of misoprostol every four hours. Although the frequency of two doses were significantly higher than the other group.
Regarding Jahromi et al. (2016) reported that there were no statistically significant differences between the numbers of administered doses. None of the women needed to receive the sixth dose of misoprostol because they all reached a Bishop score $>8$. Only 4 women in the sublingual and 7 in the vaginal group needed to take the fifth dose of misoprostol.

According to Tanha et al. (2013) there were no statistically significant differences between the vaginal and sublingual groups in the number of tablets administered or endometrial thickness after termination of pregnancy.

Dickinson et al. (2014) observed that all women included in the study received at least one dose of misoprostol. A total of $17.2 \%$ women required a second course of treatment, $20.2 \%$ in the sublingual group and $14.1 \%$ in the vaginal group.

Different routes of misoprostol have been administrated for cervical priming. Both oral and vaginal forms seem to be equally effective (Dodd and Crowther,. 2010). However, some women found the vaginal forms inconvenient and unacceptable Parveen et al. (2011) compared sublingual and vaginal misoprostol for preoperative cervical priming, prior to surgical termination and found similar preoperative side-effects within groups. However, sublingual misoprostol has the advantages like being more convenient to administer.

Pharmacokinetic studies on the different routes of the administration of misoprostol have demonstrated that sublingual misoprostol acid reaches a higher serum peak concentration with a shorter time-to-peak concentration than 
does vaginal misoprostol acid (Siwach et al., 2012).

In contrary with our results, study of Dasgupta and Singh. (2012) found that doses of misoprostol required for cervical ripening was found significantly less in combined estradiol and misoprostol group. Various studies have found induction delivery interval with vaginal misoprostol 16-20 h, which is in agreement with their study (Khadem and Khadivzadeh, 2015). On an average, 4-5 doses of misoprostol were required in their study for cervical ripening or initiation of active labor which is similar to other studies; however dose required in combined group was significantly less.

The present study showed that fetal outcome (Apgar score) in women with misoprostol + placebo ranged between 510 while in women with misoprostol estradiol was ranged between 5-10. There were no statistically significant differences between groups.

Our results were in agreement with study of MacIntyre et al. (2012) as they reported that there were no differences among the three groups as to the Apgar score.

According to Dasgupta and Singh. (2012) there were no significant difference was found in pre induction Bishop's score, fetal outcome and maternal complications.

Furthermore, Jahromi et al. (2016) observed that there was no significant difference was found fetal outcome and complications.

Regarding Tanha et al. (2013) there was no significant difference with regards to complications between the two groups.
First and foremost, among the limitations of the present study is its small sample size, which precludes exact conclusions. Also, we did not compare fever and hyperthermia, as a common complication of misoprostol, between the 2 groups. Another drawback of note is that we could not evaluate patient satisfaction due to the special design of the study and the simultaneous administration of both routes of the medication and the placebo.

\section{CONCLUSION}

Estradiol acts synergistically with misoprostol sublingually and significantly hastens the process of cervical ripening, initiation of active labor and vaginal delivery; we concluded that sublingual misoprostol seems as effective as sublingual misoprostol and Vaginal Estradiol for induction of labor at term.

\section{REFERENCES}

1. Ayati, S., Vahidroodsari, F., Farshidi, F., Shahabian, M. and Aghaee, M. A. (2014): Vaginal versus sublingual misoprostol for labor induction at term and post term: a randomized prospective study. Iranian journal of pharmaceutical research: IJPR, 13(1): 299-306.

2. Bakker R, Stephanie $P$ and Myers D (2017): The role of prostaglandins E1 and E2, dinoprostone, and misoprostol in cervical ripening and the induction of labor. Journal of Evidence-Based Women's Health Journal Society 12(5): 75-82.

3. Dasgupta E and Singh G (2012): Vaginal Misoprostol vs. Vaginal Misoprostol with Estradiol for Labor Induction: A Prospective Double-Blind Study. Journal of Obstetrics and Gynecology of India. sec 4: 233-241.

4. Dickinson, J. E., Jennings, B. G., and Doherty, D. A. (2014): Mifepristone and oral, vaginal, or sublingual misoprostol for secondtrimester abortion: a randomized controlled trial. Obstetrics and Gynecology, 123(6), 11621168. 
5. Dodd JM and Crowther CA. (2010): Misoprostol for induction of labour to terminate pregnancy in the second or third trimester for women with a fetal anomaly or after intrauterine fetal death. Cochrane Database Syst Rev. 13(5): 4901-4913.

6. Fakoor F, Mirzaei M, Naghipoor MR, Ebrahimi $H$ and Mahdavi M. (2013): Comparison between Sublingual Misoprostol and Intravenous Oxytocin in Management of Third Stage of Labor. Iran J. Obst. Gynecol. Inferti, 15:7-14.

7. Hofmeyr GJ, Gülmezoglu AM, and Pileggi C. (2010): Vaginal misoprostol for cervical ripening and induction of labour (review) London: Cochrane Database Syst Rev. 33(6): 123-129.

8. Iliodromiti, Z., Antonakopoulos, N., Sifakis, S., Tsikouras, P., Daniilidis, A., Dafopoulos, K., and Vrachnis, N. (2012): Endocrine, paracrine, and autocrine placental mediators in labor. Hormones, 11(4): 397-409.

9. Jahromi, B. N., Poorgholam, F., Yousefi, G. and Salarian, L. (2016): Sublingual versus vaginal misoprostol for the induction of labor at term: a randomized, triple-blind, placebocontrolled clinical trial. Iranian Journal of medical sciences, 41(2): 79-89.

10. Khadem, N. and Khadivzadeh, T. (2015): Comparison of the efficacy of PGE2 suppository and cervical foley catheter with pre-induction ripening of the cervix. Iranian Journal of Medical Sciences, 28(3):119-122.
11. MacIntyre, D. A., Sykes, L., Teoh, T. G. and Bennett, P. R. (2012): Prevention of preterm labour via the modulation of inflammatory pathways. The Journal of Maternal-Fetal and Neonatal Medicine, 25(sup1): 17-20.

12. Mirteimouri M, Tara F, Teimouri B, Sakhavar N and Vaezi A. (2012): Efficacy of Rectal Misoprostol for Prevention of Postpartum Hemorrhage. Iran J. Pharm. Res. 12:469-474.

13. Parveen, S., Khateeb, Z. A., Mufti, S. M., Shah, M. A., Tandon, V. R., Hakak, S., and Jan, N. (2011): Comparison of sublingual, vaginal, and oral misoprostol in cervical ripening for first trimester abortion. Indian Journal of Pharmacology, 43(2): 172-177.

14. Siwach, S., Kalra, J., Bagga, R. and Jain, V. (2012): Sublingual vs vaginal misoprostol for labor induction. J Postgrad Med Edu Res, 46(3): 138-43

15. Tanha, F. D., Golgachi, T., Niroomand, N., Ghajarzadeh, M. and Nasr, R. (2013): Sublingual versus vaginal misoprostol for second trimester termination: a randomized clinical trial. Archives of Gynecology and Obstetrics, 287(1): 65-69. 


\section{الميزوبروستول تحت اللسان مقابل الميزوبروستول تحت

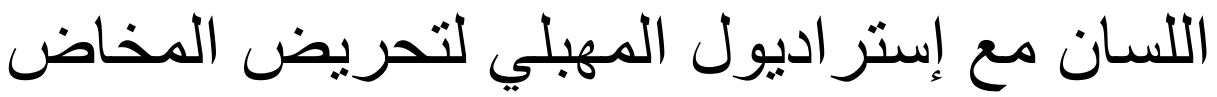 إسلام نابل عبدالحسيب، عبد لله خليل احمد، الرفاعي عبد الفتاح مرعي} أمراض النساء والتوليد، كلية الطب، جامعة الأزهر، مصر

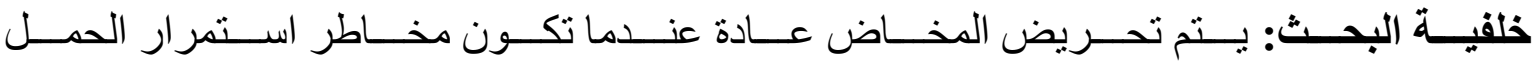

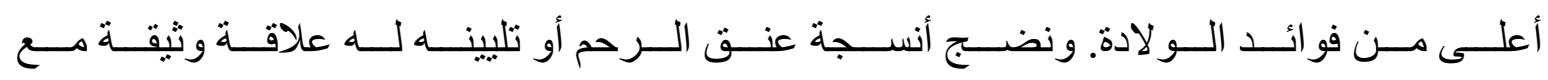
معدل نجاح الو لادة.

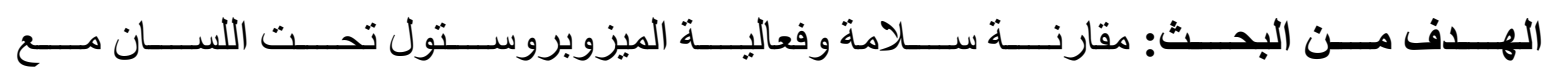

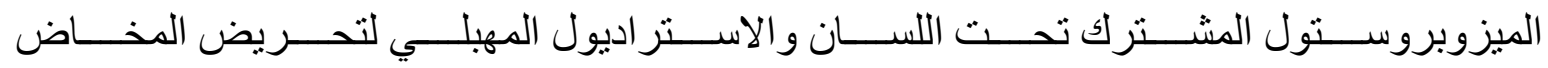
في عنق الرحم غير المواتي.

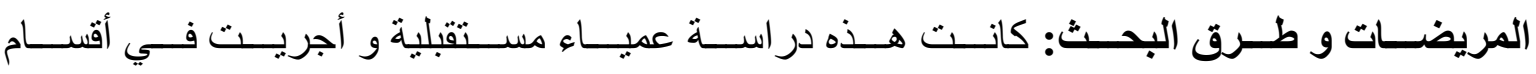

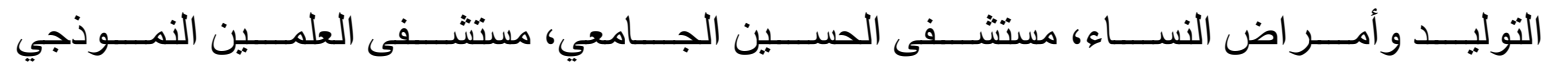

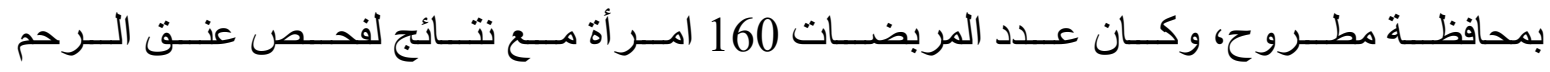

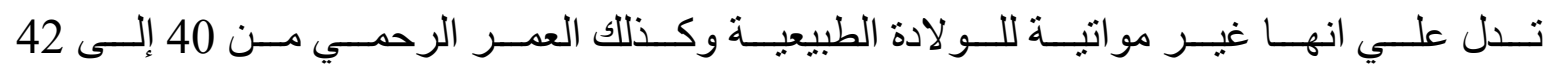

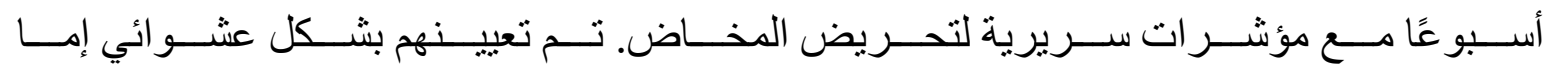

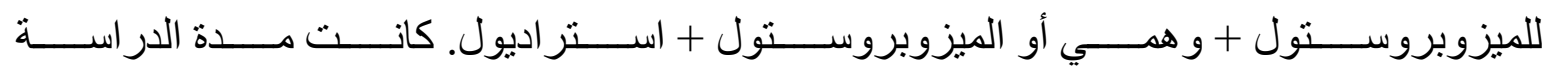
12 شهرًا من 1 مايو 2019 حتى 01 مايو 2020.

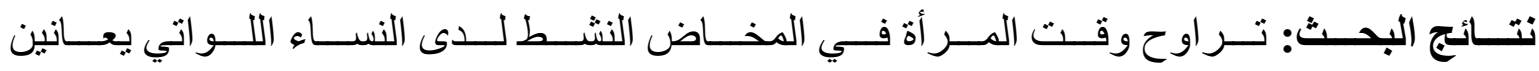

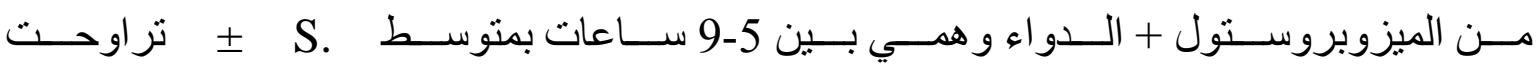
6.99

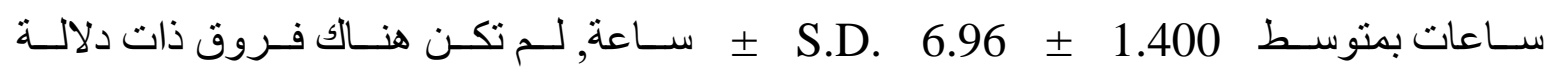

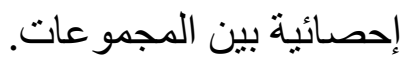

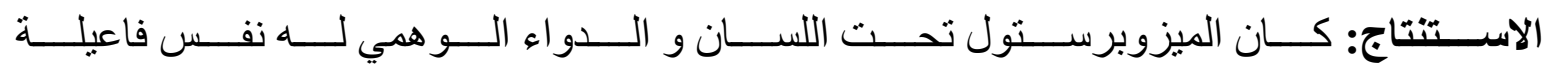

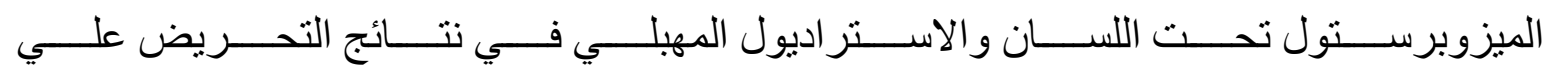
المخاض عند إكتمال العمر الرحمي للجنين. 